\title{
Current management and recommendations for access to antiviral therapy of herpes labialis
}

\author{
Anthony Cunningham ${ }^{a}$, Paul Griffiths ${ }^{b}$, Peter Leone $^{c}$, Adrian Mindel $^{d}$, Rajul Patel $^{\mathrm{e}}$, \\ Lawrence Stanberry ${ }^{\dagger}$, and Richard Whitleyg, ${ }^{*}$ \\ aWestmead Millennium Institute and University of Sydney, Westmead, NSW 2145, Australia \\ ${ }^{b}$ Centre for Virology, University College London Medical School, Rowland Hill Street, London, \\ NW3 2PF, UK \\ 'Division of Infectious Diseases, University of North Carolina School of Medicine, Chapel Hill, NC \\ 27599, USA \\ dSexually Transmitted Infections Research Centre, University of Sydney, Marian Villa, Westmead \\ Hospital, NSW 2145, Australia \\ eUniversity of Southampton, Southampton, SO14 OYG, UK \\ fDepartment of Pediatrics, Columbia University College of Physicians and Surgeons, New York, \\ NY 10032, USA \\ gDepartment of Pediatrics, Microbiology, Medicine and Neurosurgery, University of Alabama at \\ Birmingham, CHB 303, 1600 7th Avenue South, Birmingham, AL 35233, USA
}

\section{Abstract}

Herpes labialis is a common skin infective condition, worldwide, which is primarily caused by HSV-1. Recurrent episodes of herpes labialis, also known as cold sores, can be frequent, painful, long-lasting and disfiguring for infected patients. At present, there are two types of antivirals for the treatment of herpes labialis, topical and oral, which are available over the counter or as prescription-only. The aim of antiviral therapy is to block viral replication to enable shortening the duration of symptoms and to accelerate healing of the lesions associated with herpes labialis. This review examines the evidence for the effectiveness of current topical and oral antivirals in the management of recurrent episodes of herpes labialis. In most countries, oral antivirals for herpes labialis are available as prescription-only. However, in early 2010, the oral antiviral famciclovir was reclassified from prescription-only medicine to pharmacist-controlled status in New Zealand. The benefits and risks associated with moving an antiviral therapy for herpes labialis from prescription-only to pharmacist-controlled status are reviewed here, and the implications for patients, general physicians and pharmacists are considered.

\section{Keywords}

Herpes labialis; Coldsores; Famciclovir; Aciclovir; Valaciclovir; HSV-1

\begin{abstract}
Herpes labialis is a common condition worldwide. The primary cause is HSV-1, but the epidemiology has changed dramatically in recent decades. HSV-1 infection was traditionally acquired in childhood and adolescence through non-sexual contact but is now becoming the
\end{abstract}

(C) 2011 Elsevier B.V. All rights reserved

*Corresponding author. Tel.: +1 205934 5316; fax: +1 205934 8559. rwhitley@ peds.uab.edu (R. Whitley).. 
most common cause of primary genital HSV infections. ${ }^{1}$ At least $50 \%$ of new cases of herpes genitalis in developed countries are now caused by HSV-1. ${ }^{2}$ Although HSV-2 more commonly causes recurrent herpes genitalis, 3,4 it has been identified as a cause of oropharyngeal infection and herpes labialis ${ }^{5}$. The prevalences of HSV-1 and HSV-2 are generally higher in developing than in developed regions of the world, ${ }^{6,7}$ but seroprevalence rates are declining for both HSV-1 and HSV-2 in the USA. ${ }^{7}$ In eastern European countries (most notably Bulgaria), the seroprevalences of HSV-1 and HSV-2 are higher than in more northern European countries (England and Wales, Germany, Netherlands, Belgium and Finland). ${ }^{8}$ In Australia, a nationwide population-based survey reported HSV-1 and HSV-2 seroprevalences of $76 \%$ and $12 \%$, respectively, in 1999-2000, being higher in women (80.4\% and $16.3 \%$, respectively) than in men ( $71.3 \%$ and $8.9 \%$, respectively) and rising to $77.3 \%$ and $16.4 \%$, respectively, in the $35-44$-year age group. ${ }^{9}$ Higher socioeconomic status is associated with a lower prevalence of $\mathrm{HSV}-1^{5}$ and cross-sectional evaluations have identified risk factors for herpes labialis including female gender, older age (65-74 years), white race/ethnicity, frequent upper respiratory infections and low lymphocyte counts. ${ }^{9}, 10$ Smokers report fewer herpes labialis outbreaks than nonsmokers. ${ }^{10}$

Primary HSV-1 infection can be either asymptomatic or cause self-limiting gingivostomatitis in the immunocompetent host. ${ }^{11}$ The virus establishes latency in the sensory ganglia and, when reactivated, causes herpes labialis. Reactivation stimuli include exposure to ultraviolet light, ${ }^{12,13}$ fever, ${ }^{12}$ psychological stress ${ }^{14}$ and menstruation. ${ }^{15}$ Recurrent episodes of herpes labialis can be frequent, painful, long-lasting and disfiguring. ${ }^{5,16}$ In immunocompromised patients, episodes are usually longer and more severe, potentially involving the oral cavity or extending across the face. ${ }^{5,17}$ The prodrome (symptoms of reactivation) is associated with itching, burning and/or paraesthesia prior to the appearance of erythema and papule formation. ${ }^{17}$ Clinical progression evolves through the development of a vesicle, pustulation, ulceration and, ultimately, scabbing. Peak viral titres occur in the first $24 \mathrm{~h}$ after lesion onset, when most lesions are in the vesicular stage, with a subsequent progressive decline as most lesions are converted to ulcers/crust. ${ }^{17,18}$

The aim of antiviral therapy is to block viral replication in order to enable shortening the duration of symptoms and accelerate the resolution of lesions. Since the natural healing process starts within the first $24 \mathrm{~h}$ of onset of an episode, if treatment is either warranted or requested, it is imperative that therapy is initiated as soon as possible to ensure an optimal therapeutic beneficial effect. ${ }^{19}$ Two categories of antivirals are available for treatment of herpes labialis: topical and oral therapies. In this review, we examine these therapies for herpes labialis available OTC and as prescription-only, and analyse the benefits and risks associated with moving an antiviral therapy from prescription-only to pharmacist-controlled status.

\section{Current diagnosis and management of herpes labialis}

Diagnosis of herpes labialis by GPs is usually based on the patient history of this condition, the clinical signs and symptoms. Laboratory confirmation, however, may be required in immunocompromised patients if the clinical presentation is atypical.

Many patients neither require nor use any treatment because the disease is self-limiting. ${ }^{20}$ For individuals with frequent recurrences, application of a sunscreen or zinc oxide to decrease the probability of recurrent outbreaks may help. ${ }^{21,22}$ Some resort to alternative therapies available OTC for prophylaxis and/or treatment, such as herbal-based products and dietary supplements, despite unproven efficacy, ${ }^{23,24}$ or use OTC topical anaesthetics, analgesics, antipyretics, antiseptics and emollients. For many, however, the pain, unaesthetic 
and embarrassing appearance, and the social stigma warrant using approved antiviral therapy (Table 1).

A recent metaanalysis found that the therapeutic effectiveness of OTC topical anaesthetic agents and zinc-based creams in treating herpes labialis is inconclusive due to limited evidence. ${ }^{21}$ OTC topical antiviral therapies applied numerous times a day for up to 5 days are widely used. Clinical studies have shown that these products provide a small clinical benefit by reducing the duration of symptoms. ${ }^{21}$ Patients with particularly severe, frequent or complicated disease require early treatment and may also benefit from a chronic prophylaxis with a licensed systemic drug that is approved for the indication. Topical antivirals are not effective prophylactically, ${ }^{25}$ because topical application will not get the drug to the site of reactivation.

Topical antiviral medication does not impact the host immune response and consequent inflammatory cascade, but the co-administration of a topical corticosteroid may limit the inflammation. ${ }^{26-28}$ An experimental topical combination of aciclovir and hydrocortisone has proved to confer clinical benefit, but the need for frequent application (five or six times daily) would make it less convenient than high-dose, short-course oral antiviral therapy. ${ }^{29} \mathrm{~A}$ controlled trial showed that aciclovir/hydrocortisone cream significantly reduced the frequency of both ulcerative and nonulcerative recurrences in immunocompetent adults and adolescents. $^{28}$

For therapy of the initial outbreak of herpetic gingivostomatitis, oral aciclovir is of some benefit, ${ }^{21}$ by reducing the time to healing. ${ }^{30}$ The FDA, however, has not approved any antiviral agent for initial primary gingivostomatitis. For treatment of recurrent herpes labialis, a metaanalysis of five placebo-controlled and two dose-comparison studies evaluating aciclovir, famciclovir or valaciclovir indicates that oral antiviral therapy decreases outbreak duration and the associated pain by 1 day. ${ }^{31}$ However, none of the studies were head-to-head comparisons. Short-course, high-dose antiviral therapy offers greater patient and physician convenience, ${ }^{25}$ are cost beneficial, ${ }^{25,32}$ and may improve patient adherence. ${ }^{32}$

\section{Risks versus benefits of reclassification of antiviral therapy}

Despite the recent publication of an evidence-based review suggesting that oral antiviral agents are more beneficial than topical agents for treating recurrent episodes, ${ }^{21}$ antiviral tablets are currently only available by prescription (POM or Rx only) in most countries. Availability would be facilitated by a product being reclassified as a pharmacy-only (pharmacist-controlled) medicine. This is defined as a product that can be obtained without a prescription provided that a pharmacist is present at the time of sale and that the drug is controlled by the pharmacist following a patient's request. The pharmacist can query the patient to ensure that the medication is both warranted and correctly used for herpes labialis. This approach should save the patient's time and offers greater convenience, as well as affording greater personal responsibility in the therapeutic choice and early administration of the drug as first symptoms occur during the brief window of therapeutic opportunity. ${ }^{33,34}$ Furthermore, a physician's time spent in consultations and writing prescriptions may be reduced. 33

However, there are four main factors that should be considered when reclassifying a therapy from a prescription-only status to a pharmacy-only or OTC medicine: evidence of efficacy; documented safety; probability of the development of resistance; and on-going monitoring. 


\subsection{Efficacy}

The US FDA has approved short-course regimens of valaciclovir and famciclovir as prescribed oral treatments for recurrent herpes labialis ${ }^{30}$ based on efficacy results summarized in Table 2 and Fig. 1. The approval of short-course oral therapy regimen for herpes labialis is a reflection of the trend towards greater convenience and resource management in medicine, with healthcare providers, patients and payers all potentially benefiting. Such treatments are now recommended for recurrent herpes labialis having shown that they can accelerate healing and decrease pain. ${ }^{32,34}$ In addition, suppressive oral aciclovir, ${ }^{21,22}$ famciclovir ${ }^{35}$ and valaciclovir ${ }^{22}$ have all been shown to be effective for the management of severe, frequent or complicated disease.

If there is a greater ease of access to oral antiviral therapy as a result of a change to pharmacy-only status, patients may initiate therapy earlier in the course of the illness and, as a result, the treatment should be more effective. ${ }^{34}$ In addition, patient-initiated episodic therapy of recurrent herpes labialis may even prevent lesion development. ${ }^{34}$ However, it should be noted that there are no data on the effectiveness of early versus delayed antiviral therapy on herpes labialis lesions because no randomised controlled trials comparing these strategies in herpes labialis have been performed to date.

\subsection{Safety}

Clinical studies evaluating the safety of oral aciclovir, famciclovir and valaciclovir for treatment of herpes labialis have indicated that these agents are generally well tolerated and associated with minimal adverse events in patients.

The number of adverse events and drug-related adverse events was similar in a head-to-head trial of valaciclovir (1-day and 2-day therapy) vs placebo for herpes labialis. ${ }^{36}$ Headache was more common with valaciclovir than with placebo, but other adverse events, such as nausea and diarrhoea, in addition to a small number of cases of dyspepsia, dry mouth and flatulence, were recorded in all three treatment arms. ${ }^{36}$ No serious adverse events were reported. ${ }^{36}$ Data pooled from two identical trials of valacyclovir $500 \mathrm{mg}(n=49)$ versus placebo $(n=49)$ once daily for 16 weeks revealed a slightly higher incidence of adverse events in the placebo ( 29 events, $39 \%$ of patients) than in the valacyclovir arm (22 events, $33 \%$ of patients) ${ }^{37}$ In a more recent study comparing the combination of oral valacyclovir 2 $\mathrm{g}$ twice daily for 1 day and topical clobetasol gel $0.05 \%$ twice daily for 3 days with placebo, the adverse events reported were mild and infrequent. ${ }^{27}$

A randomized, placebo-controlled trial of episodic famciclovir treatment in adults found that the adverse events were similar in the placebo and two famciclovir arms $(1500 \mathrm{mg}$ once a day for 1 day or $750 \mathrm{mg}$ twice a day for 1 day). The adverse events, headache and nausea, were mild-to-moderate in intensity, ${ }^{38}$ occurring in $<10 \%$ and $<4 \%$ of patients, respectively, in each treatment group. These safety data for famciclovir support the findings from an earlier dose-ranging study in which patients received $125 \mathrm{mg}, 250 \mathrm{mg}$, or $500 \mathrm{mg}$ of famciclovir or placebo 3 times per day for 5 days initiated $48 \mathrm{~h}$ after UVR exposure. ${ }^{39}$ There were no statistically significant differences in incidence of headaches and nausea reported by patients across the four treatment groups and no serious adverse events. ${ }^{39}$ In adolescents with herpes labialis treated with famciclovir in an open-label study, adverse events were generally mild and transient. ${ }^{40}$

The importance of prompt use and/or the need for rapid relief of symptoms has been recognized by the reclassification of certain medicines. Some examples are provided in Table 3 . These products have been deemed sufficiently safe based on post-marketing studies not to require a doctor consultation. However, patients still need to be advised by a pharmacist; a key requirement of the regulatory authorities is that the manufacturers of drugs 
reclassified to OTC status must show that they are providing adequate training and education for both patients and pharmacists. A post-marketing surveillance program for oral antiviral agents will help in collating data on adverse events related to the use of these therapies.

\subsection{Resistance}

Despite the increasing use of HSV-specific antiviral agents for recurrent herpes labialis in the past 20 years, as well as a variety of other herpesvirus infections, the incidence of resistant HSV-1 strains remains low ( $<0.5 \%$ in the immunocompetent host for the commonly used anti-HSV-1 agents). ${ }^{41-44}$ In immunocompromised patients, although higher than in immunocompetent patients, rates of resistance are still low: aciclovir $7 \%$ vs $<0.5 \% 45$ and penciclovir $2.1 \%$ vs $0.22 \%$, respectively. ${ }^{43}$ Furthermore, analysis of herpes simplex isolates from immunocompetent patients with frequently recurring herpes genitalis who stopped successful suppressive aciclovir therapy after 6 years showed that there was no selection for resistance. ${ }^{46}$ Thus, while a concern, it is unlikely that development of resistance to oral antiviral agents when used episodically in immunocompetent patients will occur.

\subsection{On-going monitoring}

Although not much is known about how often people obtain prescription drugs from online pharmacies, a substantial number of patients appear willing to accept considerable risk from off-label use to gain greater access to medication. ${ }^{47}$ The potential for accidental, or deliberate, misuse of the agent across a wider range of clinical conditions needs to be addressed and monitored.

The oral antiviral agents used for herpes labialis (aciclovir, famciclovir and valaciclovir) all have POM approval for herpes genitalis, ${ }^{48-50}$ albeit usually at different dosage regimens. Despite the introduction of pharmacist controls, some might deliberately use OTC oral antiviral agents intended for treatment of herpes labialis to treat herpes genitalis, because of the stigma associated with the latter. ${ }^{51} \mathrm{~A}$ key concern is that the patient with genital herpes would miss the opportunity to receive correct and valuable medical advice, thus perhaps increasing risks of transmission and complications. Short-course therapy with some agents, using similar regimens to those for herpes labialis, has been investigated for the treatment of recurrent herpes genitalis and has been shown to be as safe as the traditional longer courses of therapy. ${ }^{52-54}$ These therapies, however, have yet to receive approval in most countries with only a few countries, such as Australia (single $500 \mathrm{mg}$ dose, followed by three doses of $250 \mathrm{mg}$ famciclovir for genital herpes) and the US (250 mg of famciclovir twice daily for suppression of recurrent episodes of genital herpes), where a short course of famciclovir has been approved. Thus, patients buying an OTC herpes labialis treatment to use for herpes genitalis treatment would be unlikely to suffer an adverse event. The small amounts of medication that are permitted when obtained OTC reduce the potential for overdosing, and most patients always or often following the directions on the OTC package insert. ${ }^{55}$

Incorrect patient's self-diagnosis, concurrent disease and non-disclosed co-medications are important concerns that should be addressed when a pharmacist advises patients seeking OTC medication. Other concerns, such as dosing adherence issues, are not specific to the OTC medication. The experience with OTC antibacterial agents have shown that education and product labelling are essential to the success of reclassification. ${ }^{56}$ Ensuring the correct diagnosis and establishing patient history is necessary for the correct treatment to be sold. Pharmacist education through training, continuing professional development and suitable approved protocols will improve pharmacy resources. ${ }^{56}$ All information provided should be consistent and relevant, and linked to additional resources so that pharmacists can refer 
patients to if they need further information. ${ }^{56}$ Patient education using targeted campaigns are specifically recommended for HSV, stressing the importance of initiating treatment during the prodrome phase. ${ }^{57}$

Lessons can also be learnt from the New Zealand experience. Reclassification of famciclovir from a POM to a restricted medicine was recommended at the 42nd meeting of the New Zealand Medicines Classification Committee. ${ }^{58}$ Pharmacist-controlled purchase of oral famciclovir for the treatment of herpes labialis was approved in early 2010. The transTasman therapeutic products agency agreement between New Zealand and Australia is likely to result in the rescheduling of famciclovir to a pharmacist-only medicine in Australia too. Based on the acceptability of reclassification of oral famciclovir in New Zealand, it is likely that the same will be sought in the rest of the world for famciclovir and the other oral antivirals. It should be noted that these moves towards OTC are being made for therapies marketed exclusively for herpes labialis, and not herpes genitalis. Indeed, a submission to switch aciclovir for herpes genitalis to OTC status was not supported in the USA. ${ }^{59}$

\section{Pharmaco-economic benefits of OTC therapies}

Generally, OTC therapies are more accessible and convenient than prescription medications and are usually cheaper because they are often generic. ${ }^{60}$ In some countries, patients may have to pay the full cost of a POM but, in others, patients may only have to pay a fixed prescription charge that could be the same or less than the OTC price. The change from POM to OTC status of medications has been the direction followed by more than 700 treatments over the past 30 years and has led to annual healthcare cost savings of over \$20 billion for US consumers. ${ }^{61}$ For example, the switch from POM to OTC status for topical hydrocortisone saved US consumers \$200 million in the first year and \$400 million in the second, taking into account both the direct and indirect costs. ${ }^{60,62}$ In Europe, switching appropriate medicines for the treatment of minor illnesses to OTC could realise an annual saving of $€ 16$ billion. ${ }^{63}$ In allergic rhinitis, ${ }^{64}$ migraine, ${ }^{65}$ emergency contraception ${ }^{66}$ and weight control, ${ }^{67}$ marked cost savings are achievable.

\section{Conclusions}

Initial diagnosis of herpes labialis should be made by GPs. With patient education, thereafter, a significant reduction in a GP's work burden, as well as cost-savings for both the patient and the GP, could result from the availability of pharmacy-controlled antiviral medication for herpes labialis. Another important consideration is reducing the delay in the start of treatment, with patients being able to self-medicate as soon as they feel the prodrome of a herpes labialis outbreak. Suitable safeguards need to be in place, such as the monitoring for safety and appropriate package labelling of the medication. In addition, if there is a change from prescription-only to pharmacy-only status for antiviral agents in the treatment of herpes labialis, surveillance systems should be in place to assess the impact on treatment of genital herpes.

Pharmacist and patient education on the efficacies of systemic and topical antiviral agents, and the importance of treatment adherence to prevent the emergence of resistance are essential. Although systemic agents have proved to be highly efficacious in the treatment of herpes labialis based on data from placebo-controlled trials, randomized-controlled trials directly comparing systemic versus topical therapies are required. The benefits also need to be communicated at the governmental and/or payer levels, using the experience with other OTC medications as examples, as well as the recent reclassification of famciclovir for herpes labialis in New Zealand. 


\section{Acknowledgments}

Competing interests AC has participated in roundtable discussions on antivirals for herpesviruses sponsored by Novartis, GlaxoSmithKline and 3M, and in clinical trials of antivirals sponsored by Novartis and GlaxoSmithKline. LS is a consultant in vaccine development for GlaxoSmithKline and Sanofi-Pasteur; and has also received funding from the National Institutes of Health. RP has participated in advisory board meetings and speaker panels for Astellas, Becton Dickenson, GlaxoSmithKline and Novartis; and also received financial support for conference attendance from Janssen, ViiV and Gilead. PL has received funding from and participated in speaker bureaus for Novartis, GlaxoSmithKline and Abbott Diagnostics.

Funding `The availability of OTC oral antivirals for cold sores' Advisory Board Meeting, held 16-17 April 2009, in Annecy, France, was sponsored by an educational grant from Novartis.

\section{Abbreviations}

$\begin{array}{ll}\text { FDA } & \text { Food and Drug Administration } \\ \text { GP } & \text { general practitioner } \\ \text { HSV-1 } & \text { herpes simplex virus type 1 } \\ \text { HSV-2 } & \text { herpes simplex virus type 2 } \\ \text { OTC } & \text { over-the-counter } \\ \text { POM } & \text { prescription-only medicine } \\ \text { vs } & \text { versus }\end{array}$

\section{References}

1. Stanberry, LR.; Jorgensen, DM.; Nahmias, AJ. Herpes simplex viruses 1 and 2. In: Evans, AS.; Kaslow, R., editors. Viral infections of humans: epidemiology and control. 4th edn. Plenum Publishers; New York: 1997. p. 419-54.

2. Gupta R, Warren T, Wald A. Genital herpes. Lancet. 2007; 370:2127-37. [PubMed: 18156035]

3. Smith JS, Robinson NJ. Age-specific prevalence of infection with herpes simplex virus types 2 and 1: a global review. J Infect Dis. 2002; 186(Suppl 1):S3-28. [PubMed: 12353183]

4. Corey, L.; Wald, A. Genital herpes. In: Holmes, KK.; Sparling, PF.; Mardh, PA., editors. Sexually transmitted diseases. 3rd edn. McGraw-Hill; New York: 1999. p. 285-312.

5. Arduino PG, Porter SR. Herpes Simplex Virus Type 1 infection: overview on relevant clinicopathological features. J Oral Pathol Med. 2008; 37:107-21. [PubMed: 18197856]

6. Looker KJ, Garnett GP. An estimate of the global prevalence and incidence of herpes simplex virus type 2 infection. Bull World Health Organ. 2008; 86:805-12. A. [PubMed: 18949218]

7. Xu F, Sternberg MR, Kottiri BJ, McQuillan GM, Lee FK, Nahmias AJ, et al. Trends in herpes simplex virus type 1 and type 2 seroprevalence in the United States. JAMA. 2006; 296:964-73. [PubMed: 16926356]

8. Pebody RG, Andrews N, Brown D, Gopal R, de Melker H, François G, et al. The seroepidemiology of herpes simplex virus type 1 and 2 in Europe. Sex Transm Infect. 2004; 80:185-91. [PubMed: 15170000]

9. Cunningham AL, Taylor R, Taylor J, Marks C, Shaw J, Mindel A. Prevalence of infection with herpes simplex virus types 1 and 2 in Australia: a nationwide population based survey. Sex Transm Infect. 2006; 82:164-8. [PubMed: 16581748]

10. Parks CG, Andrew ME, Blanciforti LA, Luster MI. Variation in the WBC differential count and other factors associated with reporting of herpes labialis: a population-based study of adults. FEMS Immunol Med Microbiol. 2007; 51:336-43. [PubMed: 17727654]

11. Opstelten W, Neven AK, Eekhof J. Treatment and prevention of herpes labialis. Can Fam Physician. 2008; 54:1683-7. [PubMed: 19074705] 
12. Spruance SL. Pathogenesis of herpes simplex labialis: experimental induction of lesions with UV light. J Clin Microbiol. 1985; 22:366-8. [PubMed: 2995436]

13. Spruance SL, Kriesel JD, Evans TG, McKeough MB. Susceptibility to herpes labialis following multiple experimental exposures to ultraviolet radiation. Antiviral Res. 1995; 28:57-67. [PubMed: 8585760]

14. Stock C, Guillén-Grima F, de Mendoza JH, Marin-Fernandez B, Aguinaga-Ontoso I, Krämer A. Risk factors of herpes simplex type 1 (HSV-1) infection and lifestyle factors associated with HSV-1 manifestations. Eur J Epidemiol. 2001; 17:885-90. [PubMed: 12081109]

15. Lorette G, Crochard A, Mimaud V, Wolkenstein P, Stalder J-F, El Hasnaoui A. A survey on the prevalence of orofacial herpes in France: the INSTANT Study. J Am Acad Dermatol. 2006; 55:225-32. [PubMed: 16844503]

16. St Pierre SA, Bartlett BL, Schlosser BJ. Practical management measures for patients with recurrent herpes labialis. Skin Therapy Lett. 2009; 14:1-3. [PubMed: 20054504]

17. Fatahzadeh M, Schwartz RA. Human herpes simplex virus infections: epidemiology, pathogenesis, symptomatology, diagnosis, and management. J Am Acad Dermatol. 2007; 57:737-63. [PubMed: 17939933]

18. Daniels CA, LeGoff SG. Shedding of infectious virus/antibody complexes from vesicular lesions of patients with recurrent herpes labialis. Lancet. 1975; 2:524-8. [PubMed: 51344]

19. Spruance SL, Overall JC Jr, Kern ER, Krueger GG, Pliam V, Miller W. The natural history of recurrent herpes simplex labialis: implications for antiviral therapy. N Engl J Med. 1977; 297:6975. [PubMed: 194157]

20. Gonsalves WC, Chi AC, Neville BW. Common oral lesions: part I superficial mucosal lesions. Am Fam Physician. 2007; 75:501-6. [PubMed: 17323710]

21. Worrall G. Herpes labialis. Clin Evid (online). 1704; 2009:ii.

22. Woo SB, Challacombe SJ. Management of recurrent oral herpes simplex infections. Oral Surg Oral Med Oral Pathol Oral Radiol Endod. 2007; 103(Suppl 1):S12, e1-18. [PubMed: 17379150]

23. Pedersen A. LongoVital and herpes labialis: a randomised, double-blind, placebo-controlled study. Oral Dis. 2001; 7:221-5. [PubMed: 11575872]

24. Milman N, Scheibel J, Jessen O. Failure of lysine treatment in recurrent herpes simplex labialis [letter]. Lancet. 1978; 2:942. [PubMed: 81954]

25. Gilbert SC. Management and prevention of recurrent herpes labialis in immunocompetent patients. Herpes. 2007; 14:56-61. [PubMed: 18371287]

26. Spruance SL, Keough MB. Combination treatment with famciclovir and a topical corticosteroid gel versus famciclovir alone for experimental ultraviolet radiation-induced herpes simplex labialis: a pilot study. J Infect Dis. 2000; 181:1906-10. [PubMed: 10837169]

27. Hull C, McKeough M, Sebastian K, Kriesel J, Spruance S. Valacyclovir and topical clobetasol gel for the episodic treatment of herpes labialis: a patient-initiated, double-blind, placebo-controlled pilot trial. J Eur Acad Dermatol Venereol. 2009; 23:263-7. [PubMed: 19143902]

28. Hull CM, Harmenberg J, Arlander E, Aoki F, Bring J, Darpö B, et al. Early treatment of cold sores with topical ME-609 decreases the frequency of ulcerative lesions: A randomized, double-blind, placebo-controlled, patient-initiated clinical trial. J Am Acad Dermatol. 2011; 64:696.e1-696.e11. [PubMed: 20851499]

29. Evans TG, Bernstein DI, Raborn GW, Harmenberg J, Kowalski J, Spruance SL. Double-blind, randomized, placebo-controlled study of topical 5\% acyclovir-1\% hydrocortisone cream (ME-609) for treatment of UV radiation-induced herpes labialis. Antimicrob Agents Chemother. 2002; 46:1870-4. [PubMed: 12019102]

30. Cernik C, Gallina K, Brodell RT. The treatment of herpes simplex infections: an evidence-based review. Arch Intern Med. 2008; 168:1137-44. [PubMed: 18541820]

31. Jensen LA, Hoehns JD, Squires CL. Oral antivirals for the acute treatment of recurrent herpes labialis. Ann Pharmacother. 2004; 38:705-9. [PubMed: 14966254]

32. Corey L, Stanberry L. Recommendations for short-course therapies in herpes genitalis and herpes labialis. Herpes. 2007; 14(Suppl 1):4A. [PubMed: 17848212]

33. Ferner RE, Beard K. Over the counter medicines: proceed with caution. BMJ. 2008; 336:694-6. [PubMed: 18369225] 
34. Whitley R. New approaches to the therapy of HSV infections. Herpes. 2006; 13:53-5. [PubMed: 16895657]

35. Simpson D, Lyseng-Williamson KA. Famciclovir: a review of its use in herpes zoster and genital and orolabial herpes. Drugs. 2006; 66:2397-416. [PubMed: 17181386]

36. Spruance SL, Jones TM, Blatter MM, Vargas-Cortes M, Barber J, Hill J, et al. High-dose, shortduration, early valacyclovir therapy for episodic treatment of cold sores: results of two randomized, placebo-controlled, multicenter studies. Antimicrob Agents Chemother. 2003; 47:1072-80. [PubMed: 12604544]

37. Baker D, Eisen D. Valacyclovir for prevention of recurrent herpes labialis: 2 double-blind, placebo-controlled studies. Cutis. 2003; 71:239-42. [PubMed: 12661753]

38. Spruance SL, Bodsworth N, Resnick H, Conant M, Oeuvray C, Gao J, et al. Single-dose, patientinitiated famciclovir: a randomized, double-blind, placebo-controlled trial for episodic treatment of herpes labialis. J Am Acad Dermatol. 2006; 55:47-53. [PubMed: 16781291]

39. Spruance SL, Rowe NH, Raborn GW, Thibodeau EA, D'Ambrosio JA, Bernstein DI. Peroral famciclovir in the treatment of experimental ultraviolet radiation-induced herpes simplex labialis: a double-blind, dose-ranging, placebo-controlled, multicenter trial. J Infect Dis. 1999; 179:303-10. [PubMed: 9878012]

40. Block SL, Yogev R, Waldmeier F, Hamed K. Safety and pharmacokinetics of a single $1500 \mathrm{mg}$ dose of famciclovir in adolescents with recurrent herpes labialis. Pediatr Infect Dis J. 2011; 30:525-8. [PubMed: 21178655]

41. Bacon TH, Boon RJ, Schultz M, Hodges-Savola C. Surveillance for antiviral-agent-resistant herpes simplex virus in the general population with recurrent herpes labialis. Antimicrob Agents Chemother. 2002; 46:3042-4. [PubMed: 12183267]

42. Sarisky RT, Bacon T, Boon R, Locke L, Nguyen TT, Leary J, et al. Penciclovir susceptibilities of herpes simplex virus isolates from patients using penciclovir cream for treatment of recurrent herpes labialis. Antimicrob Agents Chemother. 2002; 46:2848-53. [PubMed: 12183237]

43. Sarisky RT, Bacon TH, Boon RJ, Duffy KE, Esser KM, Leary J, et al. Profiling penciclovir susceptibility and prevalence of resistance of herpes simplex virus isolates across eleven clinical trials. Arch Virol. 2003; 148:1757-69. [PubMed: 14505088]

44. Piret J, Boivin G. Resistance of herpes simplex viruses to nucleoside analogues: mechanisms, prevalence and management. Antimicrob Agents Chemother. 2011; 55:459-72. [PubMed: 21078929]

45. Stránská R, Schuurman R, Nienhuis E, Goedegebuure IW, Polman M, Weel JF, Wertheim-Van Dillen PM, Berkhout RJ, van Loon AM. Survey of acyclovir-resistant herpes simplex virus in the Netherlands: prevalence and characterization. J Clin Virol. 2005; 32:7-18. [PubMed: 15572000]

46. Fife KH, Crumpacker CS, Mertz GJ, Hill EL, Boone GS. Acyclovir Study Group. Recurrence and resistance patterns of herpes simplex virus following cessation of $\ 6$ years of chronic suppression with acyclovir. J Infect Dis. 1994; 169:1338-41. [PubMed: 8195614]

47. Nielsen S, Barratt MJ. Prescription drug misuse: is technology friend or foe? Drug Alcohol Rev. 2009; 28:81-6. [PubMed: 19320680]

48. Zovirax Prescribing information. GlaxoSmithKline. Research Triangle Park; NC: Nov. 2009 27709Available at: http://us.gsk.com/products/assets/us_zovirax.pdf.

49. Famvir (famciclovir) Prescribing Information. Novartis Pharmaceuticals Corporation; East Hanover, NJ: Dec. 2009 07936Available at: http://www.pharma.us.novartis.com/product/pi/pdf/Famvir.pdf.

50. Valtrex (valacyclovir) Prescribing Information. GlaxoSmithKline Research Triangle Park; NC: Sep. 2008 27709Available at: http://us.gsk.com/products/assets/us_valtrex.pdf.

51. Fortenberry JD. The effects of stigma on genital herpes care-seeking behaviours. Herpes. 2004; 11:8-11. [PubMed: 15115631]

52. Wald A, Carrell D, Remington M, Kexel E, Zeh J, Corey L. Two-day regimen of acyclovir for treatment of recurrent genital herpes simplex virus type 2 infection. Clin Infect Dis. 2002; 34:9448. [PubMed: 11880960] 
53. Bodsworth N, Bloch M, McNulty A, Denham I, Doong N, Trottier S, et al. 2-Day versus 5-day famciclovir as treatment of recurrences of genital herpes: results of the FaST study. Sex Health. 2008; 5:219-25. [PubMed: 18771636]

54. Aoki FY, Tyring S, Diaz-Mitoma F, Gross G, Gao J, Hamed K. Single-day, patient-initiated famciclovir therapy for recurrent genital herpes: a randomized, double-blind, placebo-controlled trial. Clin Infect Dis. 2006; 42:8-13. [PubMed: 16323085]

55. Wazaify M, Shields E, Hughes CM, McElnay JC. Societal perspectives on over-the-counter (OTC) medicines. Fam Pract. 2005; 22:170-6. [PubMed: 15710640]

56. Reeves DS, Finch RG, Bax RP, Davey PG, Po AL, Lingam G, et al. Self-medication of antibacterials without prescription (also called 'over-the-counter' use) A report of a Working Party of the British Society for Antimicrobial Chemotherapy. J Antimicrob Chemother. 1999; 44:16377. [PubMed: 10473223]

57. Patel R. Educational interventions and the prevention of herpes simplex virus transmission. Herpes. 2004; 11(Suppl 3):155A-60A.

58. Minutes. 42nd Meeting of the Medicines Classification Committee, New Zealand Medicines and Medical Devices Safety Authority; 3 November 2009;

59. Sande MA, Armstrong D, Corey L, Drew WL, Gilbert D, Moellering RC Jr, et al. Perspectives on switching oral acyclovir from prescription to over-the-counter status: report of a consensus panel. Clin Infect Dis. 1998; 26:659-63. [PubMed: 9524840]

60. White Paper on the benefits of OTC medicines in the United States. Pharmacy Today. Oct.2010 68

61. Pawaskar MD, Balkrishnan R. Switching from prescription to over-the counter medications: a consumer and managed care perspective. Manage Care Interface. 2007; 20:42-7.

62. Temin P. Costs and benefits in switching from Rx to OTC. J Health Econ. 1983; 2:187-205. [PubMed: 10310393]

63. Association Européenne des Spécialités Pharmaceutiques Grand Public. [[accessed 25.07.11]] The economic and public health value of self-medication. Jun. 2004 http://www.aesgp.be/ephv/2004study.pdf.

64. Hay JW, Kaliner MA. Costs of second-generation antihistamines in the treatment of allergic rhinitis: US perspective. Curr Med Res Opin. 2009; 25:1421-31. [PubMed: 19422280]

65. Solomon GD. Reducing the cost of headache medication. Curr Pain Headache Rep. 2009; 13:22730. [PubMed: 19457284]

66. Harper CC, Weiss DC, Speidel JJ, Raine-Bennett T. Over-the-counter access to emergency contraception for teens. Contraception. 2008; 77:230-3. [PubMed: 18342644]

67. Bray GA. Are non-prescription medications needed for weight control? Obesity. 2008; 16(Silver Spring):509-14. [PubMed: 18239604]

68. Fenistil Summary of product characteristics. Novartis; Horsham, UK: Nov. 2009 Available at: http://www.medicines.org.uk/emc/medicine/21081/SPC/Fenistil Cold Sore Cream.

69. Denavir Prescribing information. New American Pharmaceutics; Cranford, NJ 07016, USA: Available at: http://www.denavir.com/downloads/Denavir_PI_122010.pdf.

70. Zovirax (acyclovir) Prescribing Information. GlaxoSmithKline UK, Stockley Park West, Uxbridge: Aug. 2008 Available at: http://www.medicines.org.uk/EMC/medicine/2186/SPC/Zovirax+Cream//\#PRODUCTINFO.

71. Spruance SL, Hamill ML, Hoge WS, Davis LG, Mills J. Acyclovir prevents reactivation of herpes simplex labialis in skiers. JAMA. 1988; 260:1597-9. [PubMed: 3411740]

72. Spruance SL, Freeman DJ, Stewart JC, McKeough MB, Wenerstrom LG, Krueger GG, et al. Treatment of recurrent herpes simplex labialis with oral acyclovir. J Infect Dis. 1990; 161:185-90. [PubMed: 2153735]

73. Raborn GW, Martel AY, Grace MG, McGaw WT. Oral acyclovir in prevention of herpes labialis A randomized, double-blind, multi-centered clinical trial. Oral Surg Oral Med Oral Pathol Oral Radiol Endod. 1998; 85:55-9. [PubMed: 9474615]

74. Raborn GW, Martel AY, Grace MG, McGaw WT. Oral acyclovir and herpes labialis: a randomized, double-blind, placebo-controlled study. J Am Dent Assoc. 1987; 115:38-42. [PubMed: 3301980] 
75. Rooney JF, Straus SE, Mannix ML, Wohlenberg CR, Alling DW, Dumois JA, et al. Oral acyclovir to suppress frequently recurrent herpes labialis A double-blind, placebo-controlled trial. Ann Intern Med. 1993; 118:268-72. [PubMed: 8380540]

76. Supply of levonorgestrel oral emergency contraception as a pharmacy medicine: A guidance on professional practice. Royal Pharmaceutical Society of Great Britain. Nov.2010

77. Practice Guidance: Azithromycin Royal Pharmaceutical Society of Great Britain. Nov.2008 


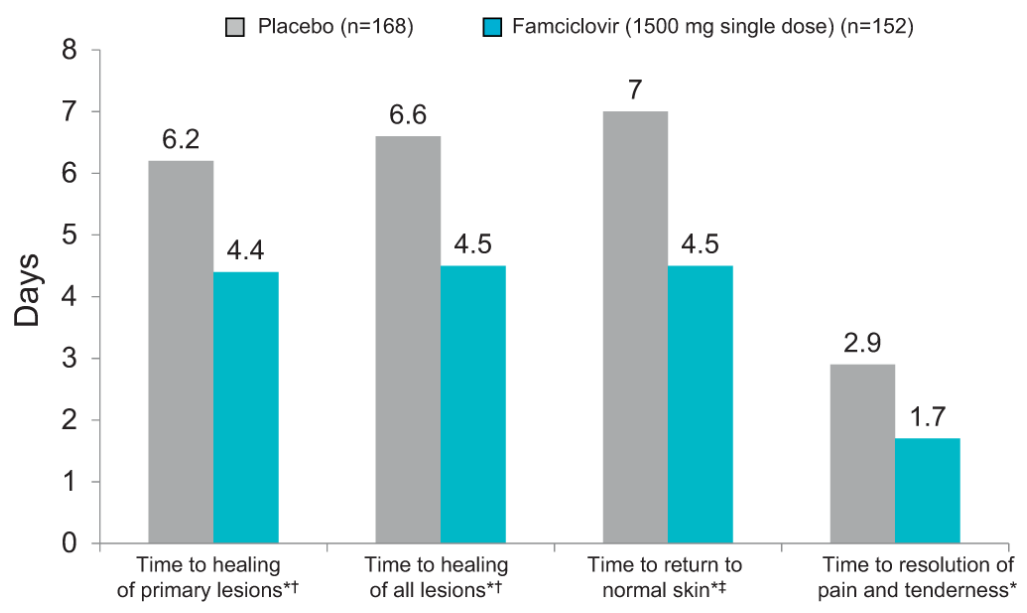

Fig. 1.

Efficacy of short-course famciclovir and valaciclovir in the treatment of herpes labialis. Famciclovir $1500 \mathrm{mg}$ single dose for 1 day significantly reduced time to healing of primary vesicular herpes labialis lesions. ${ }^{38 *} \mathrm{p}<0.001$ vs placebo; ${ }^{\dagger}$ vesicular lesions; ${ }^{\dagger}$ Normal skin defined as loss of crust, swelling, and dry flaking for all lesions (vesicular and aborted). 


\section{Table 1}

Antiviral agents approved for treatment of herpes labialis in the UK and USA.

\begin{tabular}{|c|c|c|c|}
\hline Antiviral agent [trade name] & Dosing schedule & Manufacturer & Country (legal status) \\
\hline $\begin{array}{l}\text { Penciclovir cream }(1 \%) \\
{\left[\text { Fenistil@ Cold Sore Cream }{ }^{68} \text {; }\right.} \\
\left.\text { Denavir }{ }^{\circledR},{ }^{69}\right]\end{array}$ & $\begin{array}{l}\text { Approximately } 8 \text { times daily } \\
\text { (2- hourly intervals) during } \\
\text { waking hours for } 4 \text { days }\end{array}$ & $\begin{array}{l}\text { Novartis Consumer Health } \\
\text { New American Therapeutics }\end{array}$ & $\begin{array}{l}\text { UK (pharmacist-controlled) } \\
\text { USA (Rx only) }\end{array}$ \\
\hline $\begin{array}{l}\text { Aciclovir cream }(5 \%) \\
\text { [Zovirax }{ }^{\circledR} ; 8,70 \text { Clearsore } \\
\text { Aciclovir; Action Coldsore; } \\
\text { Aviral; Soothelip; Virasorb] }\end{array}$ & $\begin{array}{l}\text { Approximately } 5 \text { times daily } \\
\text { (3-4 hourly intervals) during } \\
\text { waking hours for } 4 \text { days }\end{array}$ & $\begin{array}{l}\text { GlaxoSmithKline Consumer Healthcare } \\
\text { BTA Pharmaceuticals Inc }\end{array}$ & $\begin{array}{l}\text { UK (pharmacist-controlled) } \\
\text { USA (Rx only) }\end{array}$ \\
\hline Famciclovir [Famvir $\left.{ }^{\circledR},{ }^{49}\right]$ & $1500 \mathrm{mg}$ as a single dose & Novartis Pharmaceuticals Corporation & USA (Rx only) \\
\hline Valaciclovir (Valtrex $\left.{ }^{\circledR},{ }^{50}\right)$ & $2 \mathrm{~g}$ every $12 \mathrm{~h}$ for 1 day & GlaxoSmithKline & USA (Rx only) \\
\hline
\end{tabular}


Table 2

Summary of studies examining effectiveness of oral antiviral agents for management of recurrent herpes labialis outbreaks.

\begin{tabular}{|c|c|c|}
\hline Study design & $\mathbf{N}$ & Outcome \\
\hline \multicolumn{3}{|l|}{ Aciclovir } \\
\hline \multirow[t]{2}{*}{$\begin{array}{l}400 \mathrm{mg} \text { twice daily, } 12 \mathrm{~h} \text { before ultraviolet exposure } \\
\text { vs placebo }\end{array}$} & 147 & $\begin{array}{l}\text { Aciclovir reduced frequency of attacks and duration of symptoms overall ( } p \\
<0.05)\end{array}$ \\
\hline & & Fewer lesions with aciclovir $(7 \%)$ vs placebo $(26 \%)$ \\
\hline \multirow[t]{2}{*}{$\begin{array}{l}400 \mathrm{mg} 5 \text { times daily for } 5 \text { days vs placebo taken } \\
\text { during tingling stage }\end{array}$} & 174 & $\begin{array}{l}\text { Shorter duration of symptoms with aciclovir ( } 8.1 \text { days) vs placebo ( } 12.5 \text { days) } \\
(p=0.02)\end{array}$ \\
\hline & & $\begin{array}{l}\text { Mean duration of pain shorter with aciclovir ( } 2.5 \text { days }) \text { vs placebo ( } 3.9 \text { days }) \\
(p=0.02)\end{array}$ \\
\hline $800 \mathrm{mg}$ twice daily for $3-7$ days vs placebo ${ }^{73}$ & 237 & No significant difference in lesion occurrence with aciclovir vs placebo \\
\hline $\begin{array}{l}200 \mathrm{mg} 5 \text { times daily for } 5 \text { days vs placebo taken } \\
\text { within } 12 \mathrm{~h} \text { of the onset of the first episode }\end{array}$ & 149 & $\begin{array}{l}\text { No significant difference in healing time or pain duration with aciclovir vs } \\
\text { placebo }\end{array}$ \\
\hline \multirow[t]{2}{*}{$400 \mathrm{mg}$ twice daily for 4 months vs placebo ${ }^{75}$} & 20 & $\begin{array}{l}\text { Longer median time to recurrence with aciclovir ( } 118 \text { days) vs placebo ( } 46 \\
\text { days) }(p=0.05)\end{array}$ \\
\hline & & $53 \%$ fewer clinical recurrences with aciclovir vs placebo $(p=0.009)$ \\
\hline \multicolumn{3}{|l|}{ Valaciclovir } \\
\hline \multirow[t]{2}{*}{$500 \mathrm{mg}$ once daily for 4 months vs placebo ${ }^{21,37}$} & 98 & $\begin{array}{l}\text { Significantly longer mean time to recurrence with valaciclovir ( } 13.1 \text { weeks) } \\
\text { vs placebo (9.6 weeks) }(p=0.016)\end{array}$ \\
\hline & & $\begin{array}{l}\text { More patients were recurrence-free with valaciclovir }(60 \%) \text { vs placebo }(38 \%) \\
(p=0.041)\end{array}$ \\
\hline $\begin{array}{l}2 \mathrm{~g} \text { twice daily for } 1 \text { day vs } 2 \mathrm{~g} \text { twice daily on Day } 1 \text {, } \\
\text { then } 1 \mathrm{~g} \text { twice daily on Day } 2 \text { vs placebo }\end{array}$ & 954 & $\begin{array}{l}\text { Shorter median duration of episode with } 1 \text {-day valaciclovir ( } 5.0 \text { days; } p< \\
0.001) \text { and } 2 \text {-day valaciclovir ( } 4.5 \text { days; } p=0.009 \text { vs placebo) vs placebo ( } 5.0 \\
\text { days) }\end{array}$ \\
\hline $\begin{array}{l}2 \mathrm{~g} \text { twice daily for } 1 \text { day vs } 2 \mathrm{~g} \text { twice daily on Day } 1 \text {, } \\
\text { then } 1 \mathrm{~g} \text { twice daily on Day } 2 \text { vs placebo }\end{array}$ & 902 & $\begin{array}{l}\text { Shorter median duration of episode with } 1 \text {-day valaciclovir ( } 4.0 \text { days; } p< \\
0.001 \text { vs placebo) and } 2 \text {-day valaciclovir ( } 4.5 \text { days; } p=0.009 \text { vs placebo) vs } \\
\text { placebo ( } 5.0 \text { days) }\end{array}$ \\
\hline \multicolumn{3}{|l|}{ Famciclovir } \\
\hline \multirow{3}{*}{$\begin{array}{l}125,250 \text { or } 500 \mathrm{mg}, 3 \text { times daily for } 5 \text { days vs } \\
\text { placebo }^{39}\end{array}$} & 248 & No significant difference in number of lesions between four groups. \\
\hline & & $\begin{array}{l}\text { Famciclovir } 500 \mathrm{mg} \text { reduced median time to healing ( } 4 \text { days) vs placebo ( } 6 \\
\text { days; } p=0.010)\end{array}$ \\
\hline & & $\begin{array}{l}\text { Reduced mean lesion size in all famciclovir groups in a dose-proportional } \\
\text { manner vs placebo }\end{array}$ \\
\hline $\begin{array}{l}1500 \mathrm{mg} \text { single dose for } 1 \text { day vs } 750 \mathrm{mg} \text { twice daily } \\
\text { for } 1 \text { day vs placebo }{ }^{38}\end{array}$ & $701^{a}$ & $\begin{array}{l}\text { Reduced median healing times of primary lesions with single-dose } \\
\text { famciclovir }(4.4 \text { days; } p<0.001 \text { vs placebo }) \text { twice-daily famciclovir }(4.0 \\
\text { days; } p<0.001 \text { vs placebo) vs placebo }(6.2 \text { days })\end{array}$ \\
\hline
\end{tabular}

${ }^{a}$ Analysis only included the 477/701 (68\%) of participants who subsequently developed vesicular herpes labialis lesions during the course of treatment. 
Table 3

Examples of drugs that have switched prescribing status in the UK.

\begin{tabular}{lll}
\hline Drug & Indication & Legal status \\
\hline Chloramphenicol (1\%) eyedrops & Treatment of acute bacterial conjunctivitis & Pharmacist-controlled \\
Levonorgestrel & Emergency contraception in women aged 16 years and over ${ }^{76}$ & Pharmacist-controlled \\
Azithromycin & $\begin{array}{l}\text { Treatment of known or suspected asymptomatic } \text { Chlamydia trachomatis genital } \\
\text { infection in adults 16 years and over }\end{array}$ & Pharmacist-controlled \\
Diclofenac potassium (oral) & $\begin{array}{l}\text { For short-term relief of headache, backache, dental pain, period pain, rheumatic } \\
\text { and muscular pain, cold and flu symptoms }\end{array}$ \\
\hline
\end{tabular}

